\title{
Seroprevalence and determinants of Helicobacter pylori infection among asymptomatic under-five children at a Tertiary Hospital in the South-Western region of Nigeria
}

\author{
Adefunke O Babatola ${ }^{1}$, Felix O Akinbami², Olugbenga O Adeodu ${ }^{3}$, Temitope O Ojo ${ }^{4}$, \\ Martins O Efere ${ }^{5}$, Oladele S Olatunya ${ }^{6}$
}

1. Department of Paediatrics, Ekiti State University, Ado- Ekiti, Ekiti State.

E- mail address: mamafunky@yahoo.co.uk

2. Department of Paediatrics, Niger Delta University, Wilberforce Island, Amassoma, Bayelsa State

E-mail address: kaytoks@yahoo.com

3. Department of Paediatrics and Child Health, Obafemi Awolowo University Teaching Hospitals Complex, Ile-Ife/

Obafemi Awolowo University, Ile-Ife, Osun State

E- mail address:oadeodu2@yahoo.co.uk

4. Department of Community Health, Obafemi Awolowo University Teaching Hospitals Complex, Ile-Ife

E- mail address: linktopeojo@yahoo.com

5. Department of Biochemistry, Obafemi Awolowo University, Ile-Ife, Osun State.

E-mail address: efereo@yahoo.com

6. Department of Paediatrics, Ekiti State University, Ado- Ekiti, Ekiti State

E- mail address: ladeletunya@yahoo.com

\begin{abstract}
Background: The epidemiology of Helicobacter pylori (H. pylor in infection among under-five children in the South West Nigeria remains largely understudied. There is no data on the subject from the study area.

Objectives: This study was conducted to assess the seroprevalence of $H$. pylori infection among under-five children at a tertiary hospital in the South Western, Nigeria and to determine its associated socio-demographic factors.

Methods: Sera of 360 children were analyzed for anti $H$. pylori $\mathrm{Ig} G$ using enzyme linked immunosorbent assay test kit (BQ ELISA Ig G KIT) and H. pylori infection risk factors were determined. Determinants of H. pylori infection was determined using binary logistic regression analysis and p-values $<0.05$ were taken as statistically significant.

Results: $H$. pylori infection seroprevalence rate was $32.8 \%$ and increased with age. Living in one room accommodation, large families, playing with soil, family history of dyspepsia, practice of premastication, sharing of plates and cutlery, and water closet toilet were associated with $H$. pylori Ig $G$ seropositivity $(\mathrm{p}<0.05)$ on binary regression analysis.

Conclusion: The seroprevalence of $H$. pylori infection in under -five children is high, increasing as the age of the children increased. This may suggest that instituting preventive measures at young age, targeting identified factors may be effective in reducing the burden of $H$. pylori infection.
\end{abstract}

Keywords: Helicobacter pylori, South-Western Nigeria.

DOI: https://dx.doi.org/10.4314/ahs.v19i2.32

Cite as: Babatola AO, Akinbami FO, Adeodu OO, Ojo TO, Efere MO, Olatunya OS. Sero-prevalence and determinants of Helicobacter pylori infection among asymptomatic under-five children at a tertiary hospital in the South-Western region of Nigeria. Afri Health Sci.2019;19(2): 20822090. https:// dx.doi.org/10.4314/abs.v19i2.32

\section{Corresponding author:}

Adefunke O Babatola,

Department of Paediatrics, Ekiti State University,

Ado- Ekiti, Ekiti State

Tel No: +2348035682315 .

Email address: mamafunky@yahoo.co.uk

\section{Introduction}

Helicobacter pylori (H.pylori) infection is one of the most common human bacterial infection worldwide with about $50 \%$ of the global population infected ${ }^{1}$. The prevalence of infection varies both between and within countries in relation to race, ethnicity and geographical area $^{2}$ such that developed countries have significantly 
lower rates of $H$. pylori infection than developing countries. This difference has been attributed to differing rates of acquisition of the organism in childhood as well as sanitation, socio economic and hygiene status of the population3. Most of the infected people develop no clinical symptoms and live their lives with superficial chronic gastritis. However, about $17 \%$ of infected subjects will develop peptic ulcers and about $1 \%$ will progress to gastric cancer which is the third leading cause of cancer-related deaths in the world, especially in the adult population. ${ }^{4}$

The childhood period may be critical for the acquisition of $H$. pylori infection ${ }^{2}$. It is believed that once the organism is acquired, it persists for life unless there is an intervention $^{1,5}$. However, some authors have reported loss of infection either spontaneously in some rare cases, or as a result of inadvertent exposure to antibiotics ${ }^{6,7}$.

Documented risk factors for $H$. pylori infection include poverty, ${ }^{8}$ poor sanitation, overcrowding ${ }^{9,10}$ and unsafe water source ${ }^{11}$, which are prevalent in most communities in Nigeria.

Since the epidemiology of this bacterial infection differs from one geographical area to another and even within countries, it is therefore pertinent that more studies are conducted on people from different backgrounds in order to have better understanding of the burden of $H$. pylori infection. Hence, this study assessed the burden of $H$. pylori infection as well as the socio-economic and demographic factors that may increase the risk of childhood acquisition of infection in a semi-urban community in South Western Nigeria.

\section{Methods}

\section{Study location}

The study was conducted in two units of the Obafemi Awolowo Teaching Hospitals Complex (OAUTHC), IleIfe, Nigeria, These were the Wesley Guild Hospital unit (WGH) Ilesa and the Urban Comprehensive Health Centre unit (UCHC) Ile-ife. Ile -Ife town lies on longitude $4069^{\prime} \mathrm{E}$ and latitude $70050^{\prime} \mathrm{N} .{ }^{12}$ According to the 2006 population census, Ile-Ife has a population of 355,281 and an area of 283 sq. km. Ilesa town is located between latitude $7037^{\prime} \mathrm{N}$ and longitude 4040 ' E. ${ }^{13}$ with a population of about $277,904 .{ }^{14}$ The services rendered at these units include Infant Welfare, Nutrition Rehabilitation,
School Health, Immunization, Dental, and Physical Rehabilitation. On average, about 1,000 children aged 0-59 months are seen at the various clinics at the WGH and 2,800 children at the UCHC monthly.

\section{Study design}

We conducted a cross-sectional study between July 2014 and March 2015.

\section{Study population}

The study population comprised of children aged 6-59 months attending the child welfare clinics.

\section{Sampling methods}

On average, about 1,000 children aged 0-59 months are seen at the various clinics at the WGH and 2,800 children at the UCHC monthly. Based on this, proportionate sampling was employed in recruiting study participants. A total of 360 children between the ages of 6 months and 59 months were recruited, 265(73.6\%) from UCHC and 95(26.4\%) from WGH. Recruitment was done based on the average population of children that attend each facility. All consecutive children who met eligibility criteria were recruited and questionnaires were administered to their parents or caregivers.

\section{Data collection}

Parental social class was determined using Oyedeji ${ }^{15}$ classification method. Children who had taken antibiotics one month before presentation, those on proton pump inhibitors and those on $\mathrm{H} 2$ receptor blockers were excluded from the study.

\section{Anthropometric measurements}

Weight, length and height were measured by standard techniques as described in the supplementary materials.

\section{$H$.pylori detection}

Two milliliters of whole blood was collected aseptically through venepuncture from each participant into plain bottles. The sample was then left to clot and serum separated after spinning for 10 minutes at 4,000 revolutions per minute. The separated serum was then frozen at $-20^{\circ} \mathrm{C}$ till the time of analysis. The sample analysis was done in the laboratory of the Department of Biochem- 
istry, Obafemi Awolowo University, Ile-Ife, Nigeria. The frozen samples were thawed at room temperature. The "BQ Helicobacter pylori Ig G ELISA" kit (BQ Kits Inc. San Diego USA).was used. Each of the samples was run twice and the mean H. pylori Ig G recorded. According to the manufacturer's manual, the antibody index was interpreted as: $<0.9-$ no detectable antibody to $\mathrm{H}$. pylori Ig $G$ by ELISA, 0.9-1.1- Borderline positive $>1$ 1.1-detectable antibody to $H$. pylori Ig $G$ by ELISA

\section{Data analysis}

Data analysis was performed using the Statistical Package for Social Sciences (SPSS) version 20.0. Frequencies and proportions were used to summarize socio-demographic variables and this was presented as tables and charts. The sero-prevalence of $H$. pylori infection was determined using percentages. Chi square test of statistic was then used to determine any association between sero-prevalence and the socio demographic factors. Binary Logistic re- gression with odds ratio at $95 \%$ confidence intervals was used to assess the determinants of $H$. pylori seropositivity. Significance level was set at $\mathrm{p}$-value $<0.05$ for all tests.

\section{Ethical approval}

Ethical approval was obtained from the OAUTHC Ethics and Research Committee. Also, written informed consent was obtained from the parent or guardian of each study participant before the questionnaire was administered.

\section{Results}

Sero-prevalence of $\mathbf{H}$. pylori infection: Of the 360 study participants, $118(32.8 \%)$ were serologically positive for $H$. pylori Ig G antibodies while 242 (67.2\%) were negative.

Socio-demographic characteristics of the study participants: As shown in Table 1, there was slight male preponderance. Most of the mothers were aged between 20-39 years and virtually all the mothers $(98.1 \%)$ had formal education.

Table I: Socio demographic characteristics of participants (children aged 6 months-59 months)

\begin{tabular}{lll}
\hline Characteristics & Frequency & Percent (\%) \\
\hline Sex of participants & & \\
Males & 204 & 56.7 \\
Females & 156 & 43.3 \\
Mother's age in years & & \\
$20-29$ & 143 & 39.7 \\
$30-39$ & 200 & 55.6 \\
$40-49$ & 17 & 4.7 \\
$\geq 50$ & 0 & 0.0 \\
Mothers level of formal education & & \\
None & 7 & 1.9 \\
Primary & 33 & 9.2 \\
Secondary & 162 & 45.0 \\
Tertiary & 158 & 43.9 \\
Social class of parents & & \\
Social class 1 & 38 & 10.6 \\
Social class 2 & 99 & 27.5 \\
Social class 3 & 186 & 51.8 \\
Social class 4 & 37 & 10.3 \\
Social class 5 & 0 & 0.0 \\
Number of children in household & & \\
1 child & 102 & 28.4 \\
2 children & 126 & 35.0 \\
3 children & 70 & 19.4 \\
4 children & 43 & 11.9 \\
$\geq$ 5 children & 19 & 5.3 \\
\hline
\end{tabular}


Majority of parents (52\%) were in social class 3. No family was in social class 5 and most households had between one or two children.

Socio-demographic factors associated with $\mathrm{H}$. pylori infection:

As shown in Table 2, the sero-prevalence of $H$. pylori infection increases with advancing age of the children. Also, its prevalence increases with increasing number of children in the households $(\mathrm{p}<0.001)$. However, there was no difference in the prevalence of $H$. pylori infection with respect to mothers 'age, level of formal education and social class of the parents $(\mathrm{p}>0.05)$.

Table II: Relationship between Socio-demographic characteristics of the study participants and H.pylori seropositivity

\begin{tabular}{|c|c|c|c|c|c|}
\hline \multirow[t]{2}{*}{ Characteristic } & \multicolumn{2}{|c|}{$\begin{array}{l}\text { H. Pylori IgG sero- } \\
\text { positive }\end{array}$} & \multirow{2}{*}{$\begin{array}{l}\begin{array}{l}\text { H. Pylori IgG } \\
\text { negative }\end{array} \\
\text { Frequency }\end{array}$} & \multirow{2}{*}{$\begin{array}{l}\text { sero- } \\
\%\end{array}$} & \multirow[t]{2}{*}{$\begin{array}{l}\text { Statistical } \\
\text { comparison }\end{array}$} \\
\hline & Frequency & $\%$ & & & \\
\hline \multicolumn{6}{|l|}{ Age in months } \\
\hline $6-11$ & 15 & 12.5 & 105 & 87.5 & $\chi^{2}=49.49$ \\
\hline $12-35$ & 37 & 30.8 & 83 & 69.2 & $\mathrm{df}=2$ \\
\hline $36-59$ & 66 & 55.0 & 54 & 45.0 & $\mathrm{p}<0.001$ \\
\hline \multicolumn{5}{|l|}{ Sex } & $\chi^{2}=1.93$ \\
\hline Male & 73 & 35.8 & 131 & 64.2 & $\mathrm{df}=1$ \\
\hline Female & 45 & 28.8 & 111 & 71.2 & $\mathrm{P}=0.165$ \\
\hline \multicolumn{6}{|c|}{ Mother's age in years } \\
\hline $20-29$ & 37 & 25.9 & 106 & 74.1 & $\chi^{2}=5.66$ \\
\hline $30-39$ & 76 & 38.0 & 124 & 62.0 & $\mathrm{df}=2$ \\
\hline$\geq 40$ & 5 & 29.4 & 12 & 70.6 & $p=0.059$ \\
\hline \multicolumn{6}{|c|}{ Mothers level of formal education } \\
\hline None & 3 & 42.9 & 4 & 57.1 & $\chi^{2}=3.39$ \\
\hline Primary & 15 & 45.5 & 18 & 54.5 & $\mathrm{df}=3$ \\
\hline Secondary & 53 & 32.7 & 109 & 67.3 & $\mathrm{p}=0.336$ \\
\hline Tertiary & 47 & 29.7 & 111 & 70.3 & \\
\hline \multicolumn{6}{|c|}{ Number of children in household } \\
\hline 1 child & 16 & 15.7 & 86 & 84.3 & \\
\hline 2 children & 46 & 36.5 & 80 & 65.5 & $\chi^{2}=20.52$ \\
\hline 3 children & 29 & 41.4 & 41 & 58.6 & $\mathrm{df}=4$ \\
\hline 4 children & 20 & 46.5 & 23 & 53.5 & $\mathrm{p}<0.001$ \\
\hline$\geq 5$ children & 7 & 36.8 & 12 & 63.2 & \\
\hline \multicolumn{6}{|c|}{ Social class of parents } \\
\hline Social class 1 & 13 & 34.2 & 25 & 65.8 & $\chi^{2}=0.78$ \\
\hline Social class 2 & 29 & 29.3 & 70 & 70.7 & $\mathrm{df}=3$ \\
\hline Social class 3 & 63 & 33.9 & 123 & 66.1 & $\mathrm{p}=0.855$ \\
\hline Social class 4 & 13 & 35.1 & 24 & 64.9 & \\
\hline Social class 5 & 0 & 0 & 0 & 0 & \\
\hline
\end{tabular}

Relationships between child care practices, environmental characteristics and $H$. pylori sero-positivity: The signifi- cant factors associated with $H$. pylori sero-positivity were: practice of premastication, sharing of plates and cutlery, and accommodation type $(\mathrm{p}<0.05)$ Table III. 
Table III: Relationship between feeding history, child care practices, household characteristics of study participants and H. pylori seropositivity

\begin{tabular}{|c|c|c|c|c|c|}
\hline \multirow[t]{2}{*}{ Characteristic } & \multicolumn{2}{|c|}{$\begin{array}{l}\text { H. pylori } \\
\text { seropositive }\end{array}$} & \multicolumn{2}{|c|}{$\begin{array}{l}\text { H. pylori Ig } \\
\text { seronegative }\end{array}$} & \multirow[t]{2}{*}{$\begin{array}{l}\text { Statistical } \\
\text { comparison }\end{array}$} \\
\hline & $\begin{array}{l}\text { Frequenc } \\
\mathrm{y}\end{array}$ & $\%$ & Frequency & $\%$ & \\
\hline \multicolumn{6}{|l|}{ Mode of feeding - } \\
\hline Bottle feeding & & & & & $\chi^{2}=1.15$ \\
\hline Yes & 49 & 29.9 & 115 & 70.1 & $\mathrm{df}=1$ \\
\hline No & 69 & 35.2 & 127 & 64.8 & $\mathrm{p}=0.284$ \\
\hline \multicolumn{5}{|l|}{ Breast feeding } & $\mathrm{LR}=0.80$ \\
\hline Yes & 118 & 32.9 & 241 & 67.1 & $\mathrm{df}=1$ \\
\hline No & 0 & 0 & 1 & 100 & $\mathrm{p}=0.372$ \\
\hline \multicolumn{5}{|c|}{ Child ever attended day-care } & $\chi^{2}=1.48$ \\
\hline Yes & 39 & 37.5 & 65 & 62.5 & $\mathrm{df}=1$ \\
\hline No & 79 & 30.9 & 177 & 69.1 & $p=0.224$ \\
\hline \multicolumn{5}{|c|}{ Feeds with cup and spoon } & $\chi^{2}=0.156$ \\
\hline Yes & 115 & 33.0 & 234 & 67.0 & $\mathrm{df}=1$ \\
\hline No & 3 & 27.3 & 8 & 72.7 & $p=0.693$ \\
\hline \multicolumn{5}{|c|}{ Practice premastication } & $\chi^{2}=4.53$ \\
\hline Yes & 50 & 40 & 75 & 60 & $\mathrm{df}=1$ \\
\hline No & 68 & 28.9 & 167 & 71.1 & $p=\mathbf{0 . 0 3 3}$ \\
\hline \multicolumn{6}{|c|}{ Accommodation type } \\
\hline 1-room apartment & 26 & 59.1 & 18 & 40.9 & $\chi^{2}=18.53$ \\
\hline 2-room apartment & 40 & 25.0 & 120 & 75 & $\mathrm{df}=3$ \\
\hline 3-room apartment & 45 & 32.6 & 93 & 67.4 & $\mathrm{p}<0.001$ \\
\hline 4-room apartment & 7 & 38.9 & 11 & 61.1 & \\
\hline \multicolumn{5}{|c|}{ Share plates and cutlery } & $\chi^{2}=13.99$ \\
\hline Yes & 75 & 42.1 & 103 & 57.9 & $\mathrm{df}=1$ \\
\hline No & 43 & 23.6 & 139 & 76.4 & $\mathrm{p}<\mathbf{0 . 0 0 1}$ \\
\hline \multicolumn{5}{|c|}{ Rear domestic animals at home } & $\chi^{2}=2.33$ \\
\hline Yes & 43 & 38.4 & 69 & 61.6 & $\mathrm{df}=1$ \\
\hline No & 75 & 30.2 & 173 & 69.8 & $\mathrm{p}=0.127$ \\
\hline \multicolumn{6}{|c|}{ Family source of water } \\
\hline Well water & 68 & 38.0 & 111 & 62.0 & $\chi^{2}=5.05$ \\
\hline Stream & 3 & 37.5 & 5 & 62.5 & $\mathrm{df}=3$ \\
\hline Pipe borne water & 19 & 25.0 & 57 & 75.0 & $p=0.168$ \\
\hline Sachet water & 28 & 28.9 & 69 & 71.1 & \\
\hline
\end{tabular}

Logistic regression model for factors associated with $H$. pylori infection: Binary logistic regression model for factors associated with $H$. pylori infection shows that Under-fives who reside in houses with water closet type of toilet facility were about two times more likely to have $H$. pylori infection as compared with their counterparts who live in houses with pit latrine toilets [OR 2.40, (95\% C.I,
1.20-4.78) $\mathrm{p}=0.013]$. Also, under-fives who shared plates with other family members were almost twice more likely to have $H$. pylori infection as compared with those who did not [OR 1.79, (95\% C.I, 1.05-3.04) p=0.032]. Under-fives from homes with 1-room apartment were more likely to be seropositive for $H$. pylori when compared with their counterparts from homes with 4-room apartments 
[OR 7.51, (95\% C.I, 2.03- 27.82) p=0.003]. Children who play with soil were three times more likely to have $H$. pylo$r$ infection as compared with those who do not [OR 3.32, $(95 \%$ C.I, 1.76-6.29) $\mathrm{p}<0.001]$. Furthermore, under-fives whose caregivers practice premastication were twice more likely to be infected with $H$. pylori than those who did not. [OR 2.09, (95\% C.I, 1.23-3.56) p=0.007]. Participants with positive family history of dyspepsia were more likely to have $H$. pylori infection when compared with those with no family history of dyspepsia [OR 2.13, (95\% C.I, 1.08-4.21) $\mathrm{p}=0.029]$. Lastly, under-fives from households with two, three and four children were more likely to be seropositive to $H$. pylori than those under-fives from households with only one child.

\section{Discussion}

Helicobacter pylori infection can occur early in the life of an individual and if left untreated, could lead to chronic health problems such as peptic ulcer disease and gastric cancer in later life ${ }^{1}$. Despite, these observations, there is scanty data on the subject among Nigerian children and none from the study area. Hence, this study is an important addition to the scanty data on Helicobacter pylori infection among children in Nigeria. This is more apt giving the fact that determining the burden of this infection in childhood might aid early diagnosis and enable early therapy for identified children who meet criteria for treatment. In this study we established that Helicobacter pylori infection is common among children in our locality.

The Helicobacter pylori infection sero-prevalence rate of $32.8 \%$ found in this study compares with the $30.9 \%$ obtained by Etukudo and colleagues among children aged 6 months to 15 years $^{16}$ in Uyo, Nigeria but lower than 69\% and $65.7 \%$ found by Holcombe et al. ${ }^{17}$ in Northern Nigeria and Senbanjo et al.18 in Lagos respectively. The studies by both Senbanjo et $\mathrm{al}^{18}$ and Holcombe et $\mathrm{al}^{17}$ used participants whose average ages were older than the participants in the present study and this could account for the differences in the $H$. pylori seroprevalences as observed. Nevertheless, the sero-prevalence rate of 32.8\% found in this study, is comparable to findings from other developing countries ${ }^{9,19-22}$. For example, Kate et al. ${ }^{23}$ reported an overall sero-prevalence of $45 \%$ among children up to 15 years old in India. Also, Hestvik et al. ${ }^{22}$ reported a prevalence rate of $46.0 \%$ among less than 3 years children in Kampala, Uganda.

However, the sero-prevalence rate of $\mathrm{H}$. pylori infection in this study is higher than those reported in developed countries $^{24-26}$. Naito and colleagues reported 4.0-6.7\% among Japanese children using urine $H$. pylori antibody based test. ${ }^{24}$ Dore et al. ${ }^{25}$ obtained $13.3 \%$ amongst children aged 6-15 years in Italy. Similarly, Tam and coworkers $^{26}$ using $13 \mathrm{C}$-urea breath test reported 13.1\% among Chinese children in Hong Kong. These lower prevalence rates in developed countries could be due to the better living conditions and improved hygiene status over there.

In this study it was found that the sero-prevalence of $H$. pylori infection increases with age. This has been corroborated by many authors ${ }^{19-21,27,28}$. The reason for this, is probably

the increased opportunities for acquisition of the microorganism as a result of increased exposure to the various sources of the infection especially in children as they grow. Children are usually more mobile with increasing age and particularly in under-fives, they have less regard for hygienic practices which may facilitate acquisition of infection especially through faeco-oral mode of transmission. Some authors, however, did not observe any relationship with age $\mathrm{e}^{9,16,26}$. They opined that this may be due to spontaneous elimination of infection and loss of infection as indirect benefits from use of antibiotics for some other purposes ${ }^{29}$.

In this study, the factors found to be associated with the high prevalence of $H$. pylori infection among children included premastication of food by parents, sharing of plates and cutlery with family members, communal residing in one room apartment by families, family history of dyspepsia and having many children in the household. These findings are mixed regarding literature. Sheikhian et al. ${ }^{27}$ in Iran reported association between premastication of food by mothers and $H$. pylori infection but found no association with sharing of plates. Nabwera et al..$^{31}$ reported sharing of plates as an independent risk factor for $H$. pylori infection. In contrast, Langat et al. ${ }^{9}$ reported no association between premastication of food by mother and H. pylori infection. 
Ikpeme et al. ${ }^{32}$ in Uyo, Nigeria reported an association between $H$. pylori seropositivity and a family history of dyspepsia. This association probably corroborates the causative role of $\mathrm{H}$. pylori in dyspepsia and possible intra-family spread of the organism which was also observed by Osaki et al. ${ }^{33}$ and Nahar et al. ${ }^{34}$ in Japan and in Bangladesh respectively.

This study revealed that children who reside with parents in one room apartments were found to be seven times more likely to be infected with $H$. pylori than those who reside in houses with two or more rooms thus highlighting impacts of overcrowding in $H$ pylori infection as earlier observed ${ }^{9,20,30,35}$.

Surprisingly, the use of water closet as means of sewage disposal was found to be a risk factor for $H$. pylori infection in this study. This might be related to improper and unhygienic use of the water closet toilet facilities especially in developing countries such as Nigeria with poor access to water supply. Similar to this study, Senbanjo et al. ${ }^{18}$ in Lagos also found that people who used water closet toilet facilities had higher $H$. pylori seropositivity rate than those who did not. This is in contrast with the findings of Etukudo and coworkers ${ }^{16}$ in Uyo, who found that use of pit latrine was more likely to be associated with $H$. pylori infection in children than water closet.

There was no association between $H$. pylori seropositivity and mother's level of education. This is in agreement with findings by Oleastro et al in Lisbon ${ }^{36}$.

Our finding of no association may be because most of the mothers of the study participants were literate. However, previous authors have established link between low mother education and increased H. pylori infection ${ }^{9,26}$.

This study also revealed no association between types of feeding practice (bottle feeding, breastfeeding and use of cup and spoon) and H. pylori seropositivity rates. Sial et al. ${ }^{30}$ in Tunisia reported no association between H. pylori and breastfeeding but found prolonged bottle feeding as a risk factor, thus suggesting that the feeding bottle may be a vehicle of infection.

Langat et al. ${ }^{9}$ also found no association between $\mathrm{H}$. pylori infection and breast feeding.

\section{Conclusion}

Sero-prevalence of $H$. pylori infection was found to be high in this study and logistic regression model indicated that water closet toilet facilities, sharing of plates and cutlery, one room accommodation, playing with soil outside the house, number of children in the households, practice of premastication of food and family history of dyspepsia were associated with $H$. pylori infection. Therefore, health education targeted at parents and guardians with regards to preventing these factors will be helpful in reducing the prevalence of $H$. pylori infection in children in the study area.

In addition, since vaccination against the infection has been proposed by some researchers in developed countries as a way to combat the scourge of $H$. pylori infection, ${ }^{37}$ the findings from this study, raises the need for more longitudinal studies focusing on the evolution of dyspeptic symptoms during childhood and possibly identification of serotypes commonly responsible for $\mathrm{H}$. pylori infection in Nigeria for targets for vaccination. Also, such studies may help to identify other determinants of $H$. pylori infection. Hence, this may help government in formulating policies such as inclusion of vaccination against H. pylori infection in the routine childhood immunization schedule and improving the general housing conditions of the populace. Finally, there is a need for guidelines that could assist the clinicians in developing countries in identifying which category of children to screen and treat for the $H$. pylori infection.

\section{Limitation of the study}

This study was hospital based and has the possibility of being skewed towards severe cases of the health targeted conditions. However, the primary health care units where the study was conducted mainly care for children who are not sick but merely came for well child visitation, for growth and nutritional monitoring and immunization services. Hence, are presumed to closely reflect the community prevalence of $H$. pylori infections.

\section{Acknowledgements}

We thank all the children who participated in the study and their parents for their understanding.

\section{References}

1. Salih BA. Helicobacter pylori infection in developing countries: the burden for how long? Saudi Journal of Gastroenterology. 2009;15(3):201. 
2. Oona M. Helicobacter pylori infection in children: epidemiological and therapeutic aspects. 2004.

3. Frenck RW, Clemens J. Helicobacter in the developing world. Microbes and infection. 2003;5(8):705-713.

4. WHO. Cancer: Fact Sheet No 297. 2015. http:/ /www. who.int/mediacentre/factsheets/fs297/en/. Accessed August 28, 2015.

5. Testerman TL, James M. Beyond the stomach: An update view of Helicobacter pylori pathogenesis, diagnosis and treatment. World Journal of Gastroenterology. 2014;20(36):781-808.

6. Amberbir A, Medhin G, Abegaz WE, Hanlon C, Robinson K, Fogarty A, et al. Exposure to Helicobacter pylori infection in early childhood and the risk of allergic disease and atopic sensitization: a longitudinal birth cohort study. Clin Exp Allergy. 2014;44(4):563-571.

7. Broussard CS, Goodman KJ, Phillips CV, Smith MA, Fischblach LA, Sue Day R et al. Antibiotics taken for other illnesses and spontaneous clearance of Helicobacterpylori Infection in children. Pharmacoepidemiol Drug Saf. 2009; 18:722-9.

8. Malcolm CA, MacKay WG, Shepherd A, Weaver LT. Helicobacter pylori in children is strongly associated with poverty. Scottish Medical Journal. 2004;49(4):136-138.

9. Langat AC, Ogutu E, Kamenwa R, Simiyu DE. Prevalence of Helicobacter pylori in children less than three years of age in health facilities in Nairobi Province. East Afr Med J. 2006;83:471-477.

10. Farrell S, Doherty GM, Milliken I, Shield MD, McCallion WA. Risk factors for Helicobacter pylori infection in children: an examination of the role played by intrafamilial bed sharing. The Pediatric Infectious Disease Journal. 2005;24(2):149-152.

11. Aziz RK, Khalifa MM, Sharaf RR. Contaminated water as a source of Helicobacter pylori infection: A review. Journal of Advanced Research. 2015;6(4):539-547.

12. The office of the Executive Governor of the State of Osun. Ile-Ife. The official website of the State of Osun. 2014. [online]. Accessed on $4^{\text {th }}$ June. 2015. Available from: http://www.osun.gov.ng/about/major towns/ile-ife.

13. Orimogunje OO, Oyinloye RO, Momodu S. Geospatial mapping of wetlands potential in Ilesa, southwestern Nigeria. FIG working sheet 2009, Surveyors, keynote in accelerated development. Eliat Israel 2009:3-8.

14. National Population Commission. Osun state population by local government area and sex. (Accessed on $15^{\text {th }}$
June 2015). Available from: http://www.population.gov. ng/state/osunfinal.pdf.

15. Oyedeji Gabriel. Socio-economic and cultural background of hospitalized children in Ilesha. Nig J Paed 1985; 12:111-7

16. Etukudo OM, Ikpeme EE, Ekanem EE. Seroepidemiology of Helicobacter pylori infection among children seen in a tertiary hospital in Uyo, southern Nigeria. Pan African Medical Journal. 2012;12(1).

17. Holcombe C, Tsimiri S, Eldridge J, Jones D. Prevalence of antibody to Helicobacterpylori in children in northern Nigeria. Transactions of the Royal Society of Tropical Medicine and Hygiene. 1993;87(1):19-21.

18. Senbanjo I, Akinbami A, Diaku-Akinwumi I, Oshikoya $\mathrm{K}$, Adeyemo T, Dada O, et al. Helicobacter pylori infection among a pediatric population with sickle cell disease. Journal of the National Medical Association. 2010;102(11):10951099.

19. Naous A, Al-Tannir M, Naja Z, Ziade F, El-Rajab M. Fecoprevalence and determinants of Helicobacter pylori infection among asymptomatic children in Lebanon. Le Journal Medical Libanais. The Lebanese Medical Journal. 2006;55(3):138-144.

20. Ndip R, Malange A, Akoachere J, MacKay W, Titanji $\mathrm{V}$, Weaver L. Helicobacter pylori antigens in the faeces of asymptomatic children in the Buea and Limbe health districts of Cameroon: a pilot study. Tropical Medicine \& International Health. 2004;9(9):1036-1040.

21. Pelser HH, Househam KC, Joubert G, Van der Linde G, Kraaj P, Meinardi M. Prevalence of Helicobacter pylori antibodies in children in Bloemfontein, South Africa. $J$ Pedtr Gastroenterol Nutr. 1997;24:135-139.

22. Hestvik E, Tylleskar T, Kaddu-Mulindwa DH, Ndeezi G, Grahnquist L, Olafsdottir E, et al. Helicobacter pylori in apparently healthy children aged 0-12 years in urban Kampala, Uganda: a community-based cross sectional survey. BMC gastroenterology. 2010;10(1):1.

23. Kate V, Ananthakrishnan N, Ratnakar C, Badrinath S. Anti-H. pylori IgG seroprevalence rates in asymptomatic children and adults from South India. Indian Journal of Medical Microbiology. 2001;19(2):20.

24. Naito Y, Shimizu T, Haruna H, Fujii T, Kudo T, Shoji $\mathrm{H}$, et al. Changes in the presence of urine Helicobacter pylori antibody in Japanese children in three different age groups. Pediatrics International. 2008;50(3):291-294.

25. Dore MP, Fanciulli G, Tomasi PA, Realdi G, Delita- 
la G, Graham DY Get al Gastrointestinal symptoms and Helicobacterpylori infection in school aged children residing in Porto Torres Sardinia, Italy. Helicobacter 2012; 17:36973.

26. Tam YH, Yeung CK, Lee KH, Sihoe JDY, Chan KW, Cheung ST, et al. A Population-Based Study of Helicobacter pylori Infection in Chinese Children Resident in Hong Kong: Prevalence and Potential Risk Factors. Helicobacter. 2008;13(3):219-224.

27. Sheikhian A, Ataherian S, Delfan M, Ebrahimzadeh F, Pournia Y. Prevalence and risk factors of Helicobacter pylori infection among Health Center Referrals in Khorramabad (west of Iran). Asian J Epidemiol. 2011;4:1-8.

28. Malaty HM, Kim JG, Kim SD, Graham DY. Prevalence of Helicobacter pylori infection in Korean children: inverse relation to socioeconomic status despite a uniformly high prevalence in adults. American Journal of Epidemiology. 1996;143(3):257-262.

29. Hoffmann A, Krumbiegel P, Richter T, Richter M, Roder S, Rolle- Kampazyk U. Helicobacter pylori prevalence in children influenced by non specific antibiotics treatment. Cent Eur J Public Health 2014; 22:48-53.

30. Siai K, Ghozzi M, Ezzine H, Medjahed N, Azzouz M. Prevalence and risk factors of Helicobacter pylori infection in Tunisian children: 1055 children in Cap-Bon (northeastern Tunisia). Gastroentérologie Clinique et Biologique. 2008;32(11):881-886.
31. Nabwera HM, Nguyen- Van-Tam JS, Logan RF, Logan RP. Prevalence of Helicobacter pylori infection in Kenyan school children aged 3-15yrs and risk factors for infection. Eur J Gastroenterol Hepatol. 2000;12:483-487.

32. Ikpeme E, Etukudo O, Ekanem E. Clinical correlates of Helicobacter pylori infection in children seen at a Tertiary Hospital in Uyo, Southern Nigeria. Nigerian Journal of Paediatrics. 2013;40(1):45-49.

33. Osaki T, Konno M, Yonezawa H, Hojo F, Zaman C, Takahashi M, et al. Analysis of intra-familial transmission of Helicobacter pylori in Japanese families. Journal of Medical Microbiology. 2015;64(1):67-73.

34. Nahar S, Kibria KM, Hossain ME, Sultana J, Sarker SA, Engstrand L, et al. Evidence of Intrafamilial transmission of Helicobacter pylori by PCR based RAPD finger printing in Bangladesh. Eur J Clin Microbiol Infect Dis. 2009;28:767-773.

35. Brown LM. Helicobacter pylori: epidemiology and routes of transmission. Epidemiologic Reviews. 2000;22(2):283-297. 36. Oleastro M, Pelerito A, Nogueira P, Benoliel J, Santos A, Cabral J, et al. Prevalence and incidence of Helicobacter pylori infection in a healthy pediatric population in the Lisbon area. Helicobacter. 2011;16(5):363-372.

37. Rupnow MFT, Chang AH, Shachter RD, Owens KD, Personnet J. Cost-Effectiveness of a Potential Prophylactic Helicobacter pylori Vaccine in United States. The Journal of Infectious Diseases 2009; 200:1311-7 